\title{
About the decapitation of corpses - Reflections of Ernst Bloch's Ungleichzeitigkeit in the novels of Klaus Mann (including a glimpse into the present)
}

\author{
Manuel Theophil*
}

\begin{abstract}
With the help of the term Ungleichzeitigkeit the German philosopher Ernst Bloch tried to comprehend the emergence of Nazism. Bloch was not satisfied with the typical Marxist explanation that fascism can simply be understood as capitalism's last hope. Instead, he focused on dreams, wishes, and worldviews which seemed to be misplaced in the present and, thus, were ignored or considered as reactionary by the political left. Bloch demonstrated how the Nazis were able to exploit these Ungleichzeitigkeiten by addressing them in their propaganda. The objective of this paper is not only to introduce the notion of Ungleichzeitigkeit in its historical context but also to show in which ways this political term is reflected in the novels of Klaus Mann. As Mann, at first glance, may seem as a rather unexpected candidate for such an endeavour, the text starts with outlining the relationship Bloch and Mann had during the 1920s and 1930s. The paper ends with a brief look at today's Ungleichzeitigkeiten and their reflections in contemporary German literature.
\end{abstract}

Key words: Ernst Bloch, Ungleichzeitigkeit, nationalism, Klaus Mann, literature

\footnotetext{
* Universität Koblenz Landau; ma-th-89@hotmail.de
} 


\section{An unlikely connection?}

At first glance, the undertaking of applying a term which originates in the philosophy of Ernst Bloch to literary texts written by Klaus Mann may appear to be a fruitless endeavour. On the one hand, there is an unorthodox Marxist philosopher whose oeuvre - especially considering its core, the utopian thinking - is worldly oriented. Bloch was an advocate of what he called concrete utopias - that is, of conceptions of the future which are rooted in the possibilities reality has to offer. On the other hand, there is a highly lyrical young writer whose enthusiasm threw him from idea to idea, and for a long time none of these ideas demonstrated a deep understanding of or even an interest in the world that surrounded him. Reflecting on authors who influenced him the most in his youth (i.e. Nietzsche, Kleist, George), Klaus Mann, in his second autobiography Der Wendepunkt (The turning point) ${ }^{1}$, does not make any secret of his naiveté as a young adult concerning questions of society or politics. He clarifies that among his personal Gods of writers "the erotic-religious element dominates, whereas the social element is almost entirely neglected. Realism is hardly represented in my boy-Olympus" 2 (Mann 2006, 160). Mann was still in this phase of his intellectual development when he met Bloch for the first time in Paris in 1926 (Gekle 1985, 619). At that point, he knew (and admired) the philosopher for being the author of Geist der Utopie (Spirit of Utopia) - a book Bloch had published shortly after World War I. Highly expressionist in its language, it comes as little surprise that Mann was fascinated by Bloch's first major work. However, it is also not very astonishing that the young writer was not able to fully grasp all implications and intentions of the text. Particularly Bloch's hints towards a materialism with the principle of hope as its core (e.g. Bloch 1985f, 276-294, 411) that is, with matter which is not static but characterised by movement and thus open for worldly change as well as for the dreams of the people ${ }^{3}$ - were lost on Mann. Obviously captivated by Bloch's language, he remarked the following about the philosopher's style of writing in an article, published about a year after both had met in Paris: "No materialism speaks in such a way" (Mann 1992a, 150). It would have been true had he written: Before Bloch, no materialism has ever spoken in such a way. In fact, in order to be truth-

1 The mere fact that Klaus Mann already wrote his second autobiography when he was in his mid-thirties (1941), depicts a huge difference to Bloch. Mann always drew inspiration from personal circumstances for his work, whereas Bloch rarely reflects directly on his life in his texts. Prominent exceptions are Geist, der sich erst bildet (Bloch 2007) and Gedenkbuch für Else Bloch-von Stritzki (Bloch 1985i).

2 If not signified otherwise, translations are provided by the author.

3 In Geist der Utopie, Bloch's materialism is limited to these hints. It is described in more detail in Bloch's later works, especially in Das Prinzip Hoffnung and in Das Materialismusproblem, seine Geschichte und Substanz. 
ful to itself, Bloch's materialism had to speak in the way it did because a changing world cannot be captured by a dry and clotted language.

All in all, Mann's enthusiasm alone was not enough to grasp the essence of the ideas of Geist der Utopie (Jens and Naumann 2011, 198). And although there is a noticeable change in Mann's perception of the world in general and of literature in particular during the late 1920s and 1930s - a change which lets him focus more on social issues -, the hiatus when it comes to fundamental principles of Bloch's philosophy remains in place. When he briefly mentions Bloch in Der Wendepunkt, which was written in exile during World War II, he introduces him as an author who is linked closely to the Malik-publishing house and - more importantly - he still assigns Bloch to orthodox Marxism (Mann 2006, 447). Mann explains that it is the elimination of every transcendental aspect that bothers him most about hard-line Marxism. Everything that goes beyond economics, everything that has to do with longing, desire, and, dreams is, according to Mann, suspicious among these thinkers; alpha and omega is the doctrine of Marx (Mann 2006, 452). Even though it has to be pointed out critically that Bloch had put his hopes in the Soviet Union for way too long ${ }^{4}$, Mann's criticism underlines once more that his comprehension of Bloch's philosophy was only superficial.

However, what is also interesting about the passage in question from Mann's autobiography is that he claims to be in a friendly relationship with the philosopher (Mann 2006, 447). This cordiality was, in fact, mutual and it was based upon a shared character trait: Mann was willing to ignore differing opinions for the time being and, thus, was not shy of cooperating with communists in order to fight the Nazis - e.g. Mann took part in the First Congress of Soviet Writers held in Moscow in 1934, despite being frequently attacked by followers of a strict Marxism. This open-minded approach helped him to become acquainted with some of these thinkers to which he, as outlined above, falsely assigned Bloch as well. The philosopher dealt with opposing opinions in a similar way. Bloch did not turn his back on art, philosophical schools, or political thoughts that were condemned by Marxists for being bourgeois or reactionary. He was convinced that beneath every ideological illusion there is always something worthwhile to discover, something that deserves to be inherited. Large parts of his magnum opus Das Prinzip Hoffnung (The Principle of Hope) are devoted to this task. ${ }^{5}$ So while their

\footnotetext{
4 As the Nazis gained power in Germany, Bloch left the country. He lived in Switzerland, Austria, and Czechoslovakia before going to the United States of America in the late 1930s. From time to time he considered migrating to the Soviet Union - a plan that was presumably stopped by his wife Karola, an architect of Polish origin, who had much better knowledge of the living conditions for intellectuals in the Soviet Union.

5 In fact, this trait also shows itself at the origin of Marxism. What Marx essentially did was to form a mélange of French materialism of the $18^{\text {th }}$ century and German Idealism (notably Hegel of course).
} 
openness was definitely contributing to them being on good terms, their relationship was, nevertheless, to a great extent characterised by inequality. Bloch was more than twenty years older than Mann; both came from very different family backgrounds and - maybe most importantly - to a certain degree Bloch found himself admired by Mann. As already mentioned, it was especially Bloch's early work Geist der Utopie Mann was fascinated by.

It is remarkable that Bloch, later on and more than once, still refers to and sometimes even (presumably fully intentionally) feeds into this admiration when he exchanges letters with Klaus Mann. At that time, their communication revolved, for the most part, around Bloch's search for a publishing house for his latest work Erbschaft dieser Zeit (Heritage of this Time) - a book consisting of a series of essays linked by superordinate concepts (one of them being Ungleichzeitigkeit). Due to Mann's close friendship with Fritz Landshoff, head of the Querido-publishing house in Amsterdam, which had almost the entire German exile under contract, Bloch was hopeful that Mann could put in a good word for him. It is under these particular circumstances that Bloch frequently addressed Mann as "a colleague and one of my first readers" (Bloch 1985a, 622). He had been, as Bloch claims, among the "first friends" (Bloch 1985c, 642) of the philosopher's publications and he furthermore states to have been deeply moved by the fidelity Mann had, thus far, demonstrated towards Geist der Utopie (Bloch 1985d, 643). Regarding an opportunity to publish with Querido, Bloch's flatteries were not very successful Erbschaft dieser Zeit first came out in Switzerland with Oprecht and Helbling -, but Mann at least complied with Bloch's request to write a review (Mann 1993a). Though the text, published in Mann's own periodical Die Sammlung, was very short, it still is noteworthy because Mann was one of only very few people who took notice of the book at all at that time (Dietschy 1988, 288). In their correspondence, Bloch repeatedly expressed his lack of understanding concerning the difficulties he had to face: "Nonsense of all kinds is printed; that is and always will be the case." As the following sentences illustrate, however, his self-confidence was not shattered at all: "A book of mine is not only made for the moment, but its name carries it and will carry it. One day, fifty books will be written about this book - but now it does not find a publisher. The affair is even more boring than it is sad and shameful" (Bloch 1985b, 628f). The more Bloch's incomprehension grew, the more Mann stood out as someone who was not only willing to help in matters of publishing but also picked up central ideas of Erbschaft dieser Zeit for his essays as well as for his literary works.

From the former he inherited the focus on matter without picking up a strictly mechanistic understanding of it; from the latter he inherited dialectics without giving in to Hegel's opinion that dialectical movement is nothing more than a mere, purely idealistic soliloquy of the Weltgeist. 
In order to do so, the change in Mann's perception of the world was crucial. The more the Weimar Republic, this so often unappreciated backbone of his carefree youth in Munich and Berlin, was weakened, the more Mann's political consciousness was growing. He describes himself as an author who gained more and more insight into his moral and political obligations, especially in the course of the 1930s (Mann 2006, 509). As time passed, the clear cut between passion, emotion, and human experiences on the one hand and the political and economic sphere on the other, which he had tended to maintain during the 1920s, became more and more blurry. This process went hand in hand with his perception of Nazism. From a spectacle, which stuck out because of its stupidity and could therefore never have been taken seriously (and he took for granted that everyone else perceived the Braunhemden in the same way), the Nazis evolved in Mann's worldview to the most dangerous threat not only for Germany and Europe but for the rest of the world as well. This judgment led to self-critical questions as to whether enough had been done by the youth in general and by himself in particular to defend the democracy they had grown up in (Mann 2006, 344). Furthermore, this assessment also called for answers to the question why the Germans had handed their fate over to the Nazis.

In order to find answers to these questions, Bloch's Erbschaft dieser Zeit was of great use for Mann. It offered an argumentation that went far beyond vulgar-Marxist explanations which understood the uprising of Nazism simply as the last straw for capitalism to grasp. Bloch focussed more on energies and forces that had been ignored by left-wing politicians and which were eventually exploited by German fascism. He understood that the Nazis had been able to use the longing of the youth for risk and danger, the anger within an increasingly pauperised middle-class, and the anti-capitalist opposition within the peasantry for their own political programme (Dietschy 1988, 9). They had made, as Bloch concisely put it, their prey among people who had become anxious and uneasy (Bloch 1985e, 19). Klaus Mann reflects on Bloch's ideas not only in his review of Erbschaft dieser Zeit but also in a number of essays and in his literary texts. These reflections not only include the failure of the political left to broaden its horizon and to overthink its blind trust in what they had considered to be the unavoidable laws of economics (Mann 1993a, 249. Mann 1993b, 358) but also Bloch's notion of Ungleichzeitigkeit $^{6}$ - a term that helps explain how the Nazis were able to get hold of the desires and dreams of the people and eventually brought them in line with their propaganda.

\footnotetext{
${ }^{6}$ In the course of section 2, it will be explained why Bloch's term Ungleichzeitigkeit was not translated in this paper.
} 


\section{Ernst Bloch's notion of Ungleichzeitigkeit}

The concept of Ungleichzeitigkeit, as outlined in Erbschaft dieser Zeit, is strongly connected to a Marxist understanding of history - that is, with historical materialism. Without going into too much detail here, it can be said that Marx saw history as a series of class struggles (slave vs. slaveholder in the ancient world, bondsman vs. nobleman in the feudal system of the Middle Ages, proletarian vs. capitalist in the Early Modern Age and in modernity). In consequence, throughout history it is always one group of people who have to carry the heavy burden of drastic social change. For the capitalist period, Marx identified this group as the proletariat. From these fundamental principles of historical materialism, Bloch concluded that both the proletarian and the capitalist live at the forefront of the historical process, they are parallel to their time. Using Bloch's term, it can be said that they both live in Gleichzeitigkeit (contemporaneousness). For other groups of people or classes this is not true. The peasant, for example, is still bound to his own clod of earth; in contrast to many of his fellow citizens, they work independently and still have the means of production in their own hands. Although they share the same present with their contemporaries who live in the cities, they, nevertheless, live in a totally different time. "In the countryside there are faces that are - despite their youth - so old that the eldest people in the city do not remember them. Hardship or a more convenient opportunity drives people into the factories whereas a peasant saying goes like this: 'Work to which one is whistled to is no good."' (Bloch 1985e, 106). And it is not only a differing outlook on labour that lets the peasant appear to be misplaced in capitalist times but them being bound to nature and the seasons as well as cultural anachronisms also contribute to this impression. ${ }^{7}$

For Bloch, then, history - and that marks a huge difference to vulgar-Marxist positions - is a "polyrhythmic entity" (1985g, 618). By narrowing historical materialism to a merely schematic concept, vast parts of reality are not captured at all. A passage from Die deutsche Ideologie (The German Ideology) also demonstrates that what some of his adepts would turn his comprehension of history into would not have been in line with Marx' original interest. Marx stresses that the economic development (Unterbau) as well as the mind-set of the people (Überbau), which is closely connected with the Unterbau, evolve in different places at a different pace.

\footnotetext{
7 Of course, people in the villages also have newspapers and radio. However, for them "Egypt is still the land where the princess pulls baby boy Moses out of the river, not the land of the pyramids or the Suez Canal; the land is continuously seen from the perspective of the Bible and the children of Israel" (Bloch 1985e, 108).
} 
It follows from this that within a nation itself the individuals, even apart from their pecuniary circumstances, have quite different developments, and that an earlier interest, the peculiar form of intercourse of which has already been ousted by that belonging to a later interest, remains for a long time afterwards in possession of a traditional power in the illusory community (State, law). (Marx 1976, 83)

Marx superficially encompasses here what Bloch in Erbschaft dieser Zeit specified as the difference between real (or objective) and false (or subjective) Ungleichzeitigkeit (Bloch 1985e, 111-22). The former applies to the above-mentioned example of the peasant; his Ungleichzeitigkeit has a materialistic foundation, it has its roots in the economic development.

The situation of the petty bourgeois presents itself quite differently: Liberties once given to them in order for capitalism to spread have vanished. These people more or less live under the same conditions as the proletariat; they are dependent on others and forced to sell their labour power. But unlike the proletarian they are not willing to face this reality. They are stuck in the past. Although their earlier interest's "peculiar form of intercourse [...] has already been ousted by that belonging to a later interest," these people still live according to this long-gone interest. They hold on to a mindset that allows them to artificially differentiate themselves from the proletariat. Or in the words of Ernst Bloch: These people live in subjective Ungleichzeitigkeit. And this is, by all means, a mindset that capitalism can only benefit from because it hinders solidarity across class boundaries. These ideologies - understood as a false consciousness - were purposefully strengthened in order to distract people from their real social situation. Bloch illustrates this distraction with the help of Siegfried Kracauer's book Die Angestellten (The Salaried Masses). Detached from traditions as well as from all opportunities to give an individual shape to their lives, members of the petty bourgeoisie fled into kitsch, sports, and other shallow entertainment offered to them (Bloch 1985e, 31-41). ${ }^{8}$ This resulted in an intellectual malnourishment, making it almost impossible to enlighten this class about its real place within society.

However, Bloch considered addressing these people to be crucial in order to prevent the Nazis from getting hold of them. While doing so, the peculiarities of Ungleichzeitigkeit have to be taken into account. The fact that Bloch did not see people living in Ungleichzeitigkeit as merely reactionary or backward is important in this context.

\footnotetext{
8 Kracauer himself grasped Ungleichzeitigkeit within the petty bourgeoisie (avant la lettre so to speak): "The position of this class in the economic process has changed, but their middle-class view on life stayed the same. They nurture a false consciousness. They want to stick to differences, the acknowledgement of which darkens their situation" (Kracauer 1974, 81).
} 
He stressed that there is - despite every potential materialistic or ideological difference compared to those classes living in Gleichzeitigkeit - always an anticapitalistic element. Again, this can be explained via the example of the peasant: By doing their work the way they think is best, by not wanting to have a superior and by keeping the means of production in their own hands, they stand in a contradictory relation to capitalism. The same is true for the petty bourgeois whose ideologies are not entirely deceptive but at the same time demonstrate a longing for a better life the present state of affairs is unable to provide. And this longing, too, can be seen as an antithesis to capitalism. These are definitely not contradictions similar to those of the class-conscious proletarian, but, nevertheless, they reveal elements that are worthwhile considering and eventually valuable to inherit (hence, the title of the book: Heritage of this Time). In short, within every Ungleichzeitigkeit there is always an element of Gleichzeitigkeit. And here lies the reason why the term is not translated in this paper. Since Ungleichzeitigkeit is a rather unusual word, Bloch might have intended to use it in a way that normally a figure of speech is used - that is, to alienate the language in order to make the reader aware of the very fact that the term is not fully understood when the entire focus lies on its negation. That exactly would have been the case with translations like "asynchronism" or "non-parallelism".

The main conclusion Bloch drew from his findings was that he insisted on the necessity of addressing people living in Ungleichzeitigkeit in a specific way by left-wing politicians and intellectuals. Simply reusing speeches and texts that had been written in order to form a class-conscious proletariat would not be sufficient. Bloch demanded to find an address that would respect the living conditions of the peasant or the petty bourgeois and that takes their desires and dreams as well as their fears into consideration. He called for a popularisation of language without vulgarising the issues at hand (Bloch 1985g, 245). According to Bloch, the social democrats and communists of the 1920s and 30s had failed to do so. This can be illustrated by a personal anecdote Bloch told in an interview, first published in the periodical Kursbuch: Just before the Nazis took over power in Germany, Bloch attended a political gathering in the Sportpalast in Berlin. At that particular meeting, Nazis as well as communists gave speeches. First it was a communist's turn to talk. And he started by throwing very specific Marxist terms and endless economic numbers at the audience. He talked in his own jargon which, in consequence, led to him talking more or less to himself. Soon, no one was listening anymore. Analysing the situation rhetorically, one can say that the communist did not take the aptum - the adequacy of the speech in relation to audience and topic - into account. Then a Nazi stepped to the microphone and politely thanked the communist for his remarks because with what he had just said he had confirmed a wisdom of the 
Fuehrer Adolf Hitler: By presenting numbers and numbers and even more numbers, he had demonstrated that communism and capitalism are basically two sides of the same coin (Bloch 1985i, 211f.).

The communists talked about the issues but did not address the people; the Nazis obscured the issues but were able to address the people (Bloch 1985e, 153). And they did so by purposefully taking advantage of the inability of social democrats and communists to explain their own approaches and goals. To a great extent, Nazi propaganda was nourished by occupying topics ignored or insufficiently addressed by the political left. In Bloch's anecdote, they were able to disguise themselves as the real anti-capitalist force - a role they of course never intended to take on. ${ }^{9}$ Bloch called this the revolutionary illusiveness of the Nazis (Bloch 1985e, 71), and it did not stop by taking over narratives from the political left. Nazism also adopted the red colour (which was now the background for the swastika) and strategies of mobilising huge crowds of people (gatherings, singing along to catchy melodies etc.). The common Nazi tried to give the impression of being "a rebel, even a socialist one, one from the worker's party" (Bloch 1985h, 145). This deceit also reveals itself by taking a closer look at the party name: NSDAP (National Socialist Worker's Party of Germany). The Nazis claimed to be a socialist workers' party, but at no time were they interested in changing the economy or improving the situation of the workers. The fate Nazism had in mind for the 'German worker' was to use him as a soldier for their inevitable war. All in all, the Nazis capitalised on the anti-capitalist atmosphere caused by the Weimar Republic and the economic crisis at the end of the 1920s. To a great extent, this atmosphere was - due to Ungleichzeitigkeit in many social classes - vague; what the fascists then did was to transform it into mass murder, carried by a booming war time economy. Soon, anti-capitalism simply meant to kill the Jews who had been branded as usurers (1985e, 34). So, while capitalism during the 1920s used Ungleichzeitigkeit for dispersion, the Nazis later used it for their racial fanaticism.

Other examples that show how Nazi propaganda could capitalise on Ungleichzeitigkeit are the Fuehrer-principle or the self-attribution of the Nazis to live in the "Third Reich". The former was built, according to Bloch, upon a deeply rooted, anthropological longing for a personal role model providing orientation. People had sought (and still seek) this kind of orientation in father figures within their personal environment as

\footnotetext{
9 In his overview of the German exile, written with his sister Erika, Klaus Mann briefly mentions this aspect by referring to a discussion between Hitler and Otto Strasser, which took place in May 1930. Strasser was a right-wing politician. Up until July 1930 he was also a member of the NSDAP. Whereas Hitler focussed on race and Fuehrer-principle, Strasser emphasised the socialistic element within the nationalist movement (without giving up racism and antisemitism entirely). In the discussion in question, Strasser asked Hitler what he would do for example with the Krupp AG concerning ownership or profit after gaining power. Hitler's answer was as follows: nothing (Mann and Mann 1996, 134-36).
} 
well as in liberator figures within history (Alexander the Great, Jesus, Augustus, Prester John, etc.) (cf. Bloch 1985e, 128-32). By merely focussing on economic figures, a vulgar Marxism had nothing to offer to satisfy this desire. The same is true for religion: The name "Third Reich" has religious connotations attached to itself. It is tied to a succession, seeing in the Gospel of the Father (Old Testament) the first empire, in the Gospel of the Son (New Testament) the second empire, and in the future empire of the Holy Ghost the third and final one. The Nazis simply replaced the Holy Ghost with Hitler, Goering, and Goebbels and started to talk about an empire that would last a thousand years. And this phrase too is taken from the Bible, namely from the Book of Revelation of St. John: "And I saw thrones, and they sat upon them, and judgment was given unto them: and I saw the souls of them that were beheaded for the witness of Jesus, and for the word of God, [...] they lived and reigned with Christ a thousand years" (Revelation 20:4). So, originally the 'thousand years' referred to an empire of freedom and justice established for righteous people. In this way it was understood during the Middle Ages, for example by the abbot Joachim di Fiore, or during the Peasants' Wars (Bloch 1985e, 132-40). The Nazis then appropriated the phrase and twisted it for their fascist ideology. It then stood for an empire of hatred and suppression.

Again, what Bloch repeatedly emphasised, while tracing these roots of Nazi propaganda, was that Ungleichzeitigkeit is not bad per se. That people look out for some sort of salvator mundi or dream of a paradise-like society in which the good thrive while the bad have to face the consequences of their actions was not the problem. On the contrary, these wishes can be seen as a detector for an unsatisfactory present. The problem actually was that the political left ignored these dreams and saw them merely as reactionary. They condemned them almost to the same extent they condemned fascism. The "difference between Ungleichzeitigkeit and its fascist deceit was denied" (Bloch 1985e, 123f.). Klaus Mann, coming from a totally different intellectual background, did not make this mistake.

\section{Reflections of Ungleichzeitigkeit in the novels of Klaus Mann}

As mentioned above, Mann's writings from the 1920s and early 1930s only show little comprehension of politics or interest in social issues. At that time, he was mainly concerned with the living situation of young artists in European metropolises. His literary texts usually dealt with personal problems or with questions concerning a bohemian way of life. It was the same milieu Mann's own life took place in. In his second auto- 
biography, he critically reflects on this cosmopolitan uniformism: According to Mann, there was not much difference between whether one sat in a café in Paris, Vienna, or Berlin; "concerning the others, one could always take for granted a certain knowledge and certain experiences that were of importance to oneself; one loved the same poets, the same painters and composers, the same sceneries, rhythms, games and gestures" (Mann 2006, 298). On the occasion of a radio discussion in the early 1940s with Wystan Auden, an American writer and friend of Mann's, Auden described this enclosed bubble as an almost unavoidable result of an artist's life: An author who has a little bit of success is granted with a mobility which inevitably removes them from everyday life and, thus, estranges them from social issues. Consequently, their political opinions are necessarily deformed, which is why they should keep the political sphere out of their writings (Mann 2006, 572f). Mann showed many symptoms of Auden's diagnosis during the 1920s. Especially his highly cosmopolitan and pacifist idea of a unified world without any nation states - an idea which was mainly an amalgam of his fragmentary knowledge of Bloch's Geist der Utopie and Coudenhove-Kalergi's concept of Paneurope - was hardly in touch with the problems of that time. Furthermore, it found only little reflection within Mann's literary works. However, this changed in the early 1930s - and it changed in accordance with the answer Mann later (while preparing the radio discussion in question) gave to Wystan Auden: Although it might be true that artists are to some degree detached from the rest of society, he insisted that they can nevertheless identify that there are dogmas and worldviews which are closer to reality and truth than others. This results in a moral responsibility to make choices, which in turn find their reflection in clearly positioning oneself. What Mann, of course, had in mind at that point in time was the barbarism of the Nazis - it was fascism that had made him realise ( $\mathrm{t}$ )his moral responsibility.

In his literary texts, this change is reflected only gradually. It starts with introducing minor characters which do not belong to the above-mentioned bubble of a bohemian lifestyle. In his novel Treffpunkt im Unendlichen (Rendezvous in Infinity), published in 1932, it is for example young Willi Müller - 19 years of age and living with his brother in Berlin - who fits into this category. He once had work on a farm in East Prussia, but the business had to close down. So, he came back to Berlin, struggled finding a new job and eventually became a follower of Nazism. When he calls the Nazis "Germany's hope" (Mann 1984, 140), his family reacts uncomprehendingly, but at the same time shies away from open confrontation. In one scene of the novel, a group of artists and intellectuals meet in a flat when suddenly they hear an uproar (Mann 1984, 14147). The noises are caused by Nazis marching through the streets - among them young Willi Müller. Coincidentally, a companion of Müller looks up and sees the group of 
artists gazing at them through the window. He asks whether those people are comrades. Müller answers no, they are Jews and will hang soon enough. This scene does not only depict two different worlds by simply confronting them but undermines this confrontation and estrangement within a society by its spatial organisation. The intellectuals are positioned in the apartment above the people on the street; they are in no way connected to them and look down on them. This impression is furthermore strengthened by the topics which were discussed in the apartment before the disturbance from the street. First, the consequences of drug abuse were debated, followed by speculations when it will be possible to fly to the moon. These subjects contribute to perceiving the spatial distance between the two groups as even bigger than it actually is. (The fact that Mann describes a situation in which it is already too late - the Nazis want to kill the people in the apartment - will be discussed later.)

Given this background, other passages of Treffpunkt im Unendlichen can be read as attempts not only to bring attention to this huge hiatus between groups within society but also as an effort to reduce this gap. When, for example, another character, also a young man, comes into a bar and one of the writers present (a friend of the young man's mother) buys him a meal, the narrator comments the character's remark that he is unemployed as follows: "'Unemployed' - word from another world, word with a heavy weight attached to it that falls into the perfumed, joyful establishment” (Mann 1984, 72). The same intrusion of reality shows itself at an evening party. A theatre critic reflects on the significance of his work: "In fact, everything else is more important. One is almost ashamed to death when hearing about four million people in unemployment or that half a million Chinese simply starved to death. However, one still continues writing this empty chatter" (Mann, 1984, 72).

The question whether personal happiness is justified in times of general misery stands at the centre of Mann's book Flucht in den Norden (Escape to the North). In this novel Mann follows a young woman, Johanna, who - through one of her friends - gets in contact with communist circles in Berlin. Because of these acquaintances, she eventually has to flee and decides, for the time being, to go to another friend (Karin) in Finland. There she falls in love with Karin's brother (Ragnar). In addition to the political sphere being very present in this work, this sphere for the first time shows clear traces of Ungleichzeitigkeit. This is true, for example, for Johanna's parents whose liberalism places them somewhere around the year 1900 and consequently outside of the political struggles of their time. The barbarism of the Nazis is as alien to them as the socialist ideals of their daughter. Even more clearly, Ungleichzeitigkeit reveals itself within the family who offers refuge to Johanna. Originally from Czarist Russia, there are many elements of feudalism that have survived within this family. When Johanna describes the 
living conditions in Nazi Germany, the reactions oscillate between surprise and disbelief. More than once the lady of the house insists that the situation in Bolshevik Russia is even worse - especially compared to life under the Czar. The old lady revels in a longgone feudal past. ${ }^{10}$ At the same time, this past lets her have a favourable outlook on a country that apparently has a strong leader. In her view, Hitler and his companions give Germany a strict regime which is much better than any revolution because an uprising of the people always results in chaos (Mann 2003, 47). ${ }^{11}$

The remarks of Karin's brother Jens - when it comes to German fascism - are less materialistically anchored but instead highly ideologically charged. He enjoys exactly the kind of 'liberalism for the few' that Wystan Auden talked about (financed not by the merits of his abilities but by the 'old money' of his family). He travels back and forth from America to Europe, only superficially comprehending what is going on in both parts of the world. His view of Germany is mainly shaped by the country's art and philosophy from the $19^{\text {th }}$ century (Mann 2003, 18, 20, 45). He has a culturally saturated nation in mind, which is impossible for him to connect with the cruelties Johanna accuses her fatherland of. This kind of Ungleichzeitigkeit that detached people from politics because they saw issues of this sort as something not worthy of discussion was widely spread at that time, especially among the bourgeoisie and petty bourgeoisie. By some, it was used as a means to justify Germany's historical Sonderweg, explaining that the German nation has its roots in culture rather than in democracy - one of the most famous texts in this context, Die Betrachtungen eines Unpolitischen (Reflections of an Unpolitical Man), was written by Klaus Mann's father Thomas. ${ }^{12}$

While completely turning one's back at politics was one extreme, the other is demonstrated by vulgar Marxism. They believed in socialism to rise as surely as the sun does every morning. This issue, too, is reflected in Mann's literary works, for example in his novel Der Vulkan (The Volcano). This text offers an overview of different types of expatriates. It follows artists, intellectuals, students, and political activists leaving Germany because of the Nazi takeover. Some of them find the strength to fight back from abroad,

${ }^{10}$ A similar type of old lady appears in Mann's early novel Der fromme Tanz (The Pious Dance). She is a baroness and the aunt of the main character. The narrator describes her as follows: "Around her meagre mouth and around her lean neck, which was decorated - as a sign of former splendour - with pearls, appeared a twitch and in her frightened eyes laid the misery of an entire endangered class" (Mann 2004, 41).

${ }^{11}$ Mann quite early on argued in favour of an alliance between the capitalist West and the communist East in order to stop Hitler. He did not share the opinion popular among conservatives that the Soviet Union is the bigger threat compared to Nazi Germany (Mann 2006, 548f.).

12 The clearest view on politics within the Mann family had Thomas Mann's brother Heinrich. With the character of Diederich Heßling from his novel Der Untertan (The Subject), published in 1905, he anticipated the typical Nazi a few decades before they actually appeared. 
some gradually lose hope as time passes by. Some simply decide to start all over again in a new country, some lose their lives in the fight against fascism in the Spanish Civil War. One, comparatively small, mosaic in this picture is the love story between Tilly von Seydewitz and Konni Bruck. She comes from an upper-class family, whose wealth slowly but steadily diminishes, while he is a student of physics and a political activist for the communists. As she flees to Switzerland with her family, Konni decides to stay in Berlin for a couple more weeks. He eventually gets arrested by the Nazis and is put in a concentration camp. Concerning Ungleichzeitigkeit, what is particularly noteworthy here is not only the reaction of Tilly's mother when she hears the news ("Poor chap! [...] but why does a bright young man get involved with the dirty business of politics in the first place? I always knew that this would not end well." - Mann 1981, 74) ${ }^{13}$ but also Konni's naïve outlook on Marxism: According to the narrator, he "believed with a confidence - that answered to every objection with a proud shrug - that Marxist dogmas and prophecies were true in the same objective, indisputable way like the laws of nature or mathematical rules." (Mann 1981, 72f). This is exactly the kind of vulgar, narrow understanding of Marxism that Bloch criticised again and again. The vulgar Marxists ignored everything they considered primitive or utopian, whereas the Nazis took advantage of this very ignorance. "Hell as well as heaven, the berserks as well as theology were handed over to the reaction without putting up a fight." (Bloch 1985e, 66f.)

While the aforementioned passages from Mann's literary texts, on the one hand show different kinds of Ungleichzeitigkeit and on the other hand demonstrate how they were disregarded by the political left, an illustration of how the Nazis exploited Ungleichzeitigkeit is still owed here (with the exception of Willi Müller from Treffpunkt im Unendlichen). This void can be filled with the example of a minor character from Mann's novel Mephisto. To a great extent, this book is based on the life of the real actor Gustav Gründgens, who, during the late 1920s, was a friend of Mann (he was also married for a short time to Klaus' sister Erika). Their friendship ended when Gründgens decided to cooperate with the Nazis in order to save his acting career. Quite similarly to his uncle Heinrich and his novel Der Untertan (The Subject), Mann depicted with Hendrik Höfgen (the personage that is based on Gründgens) a certain kind of character representative for many other people of that particular time - in this case someone who is willing to come to terms with mass murderers, if only this benefits his personal goals. However, when it comes to Ungleichzeitigkeit, the minor character of Hans Miklas is

\footnotetext{
${ }^{13}$ It is also interesting to consider what Tilly's mother thinks about fascism and communism: "Those Nazis are even worse than the communists. Concerning the latter one at least knows what they are: our enemies. The Nazis pretend to be the guardians of our holiest goods, but in fact they are just disrespectful plebs” (Mann 1981, 70).
} 
far more interesting than Höfgen. At the beginning of the novel, they both work together in a theatre in Hamburg. Miklas is a young actor in his early 20s, who came from rural Bavaria to Northern Germany in order to pursue an acting career. His childhood was not very happy; his father had died in World War I and his mother did not accept his decision to become an actor. After coming to Hamburg, he soon has to face problems. His colleagues are sometimes looking down on him and treat him like a child. He does not get the roles he thinks he deserves, which stirs up his hatred, especially towards a thriving Höfgen. On top of that, he also struggles financially because his salary is not very high. All in all, he is very lonely and searches for some kind of direction - something that makes him the perfect target for Nazi propaganda. He is among the anxious and uneasy people Bloch talked about (1985e, 19). So, eventually, Miklas turns towards the Nazis and as he starts to make anti-Semitic comments in the theatre it is a socialist among the actors, Otto Ulrichs, who tries to find an explanation for what happened to Miklas:

At heart Hans is a good guy [...]. I don't think he is entirely lost for a good cause. His rebelliousness, his general discontent landed in the wrong spot [...] - today there are millions of young people like Miklas. They have hatred which is good because it is directed towards the status quo. But then a young fella has bad luck and falls into the hands of those who corrupt him; and they ruin his good hatred. They tell him that the Jews are the cause of all maladies, and the Treaty of Versailles, and he believes this nonsense [...].

This is the notorious distraction tactic. (Mann 1986, 36f)

Otto Ulrichs' argumentation reveals the clearest marks the notion of Ungleichzeitigkeit has left in Klaus Mann's oeuvre. There is the urban-rural difference, the longing for something to believe in, the struggles to keep one's head up in times of financial hardship, hence, the anticapitalist element, its exploitation by the Nazis, and finally also the lies and argumentative shortcuts of fascism. As time goes by, Miklas more and more comes to realise that his firm belief in a national socialism is not shared by those he put his faith in. "What the Nazi agitators once had loved to call the 'fat-cat economy' did not stop to exist but became even worse." (Mann 1986, 222) And unlike so many others, Miklas is neither willing nor able to hide his disappointment. He speaks up, increasingly louder the more he realises the betrayal he got himself into - and one day he ultimately gets picked up by some of his comrades who drive with him to a forest and shoot him in the back. The narrator of the novel precisely captures Miklas' fate with the following words: "The heads of those rolled whose only fault was not to let go of their socialist sympathies - and the Messiah, too, who executed them, called himself 
a socialist." (Mann 1986, 318) And if Miklas had not realised the scam and had kept his mouth shut, he would have seen the fulfilment of his revolutionary dreams in the torment of the Jews, just as a group of people in Mann's novel Der Vulkan does. And while they abuse an old Jewish man in the streets of Vienna, their victim addresses them in his thoughts: "Do you really believe in a better future because today you are allowed to harass some Jews? Do you really believe this is the revolution? You have to be really narrow-minded to be betrayed that easily!" (Mann 1981, 502)

\section{A glimpse into the present}

In a way Bloch was too late, and so was Mann. When Erbschaft dieser Zeit was published in 1934, the Nazis had already taken over power in Germany. And when Mann took the notion of Ungleichzeitigkeit into consideration for his literary texts, he had already been in exile for a long time. He himself reflects on this problem in his autobiography. He writes about two of his friends, both from the proletarianised petty bourgeoisie, and both neither with much knowledge of the world nor with any goals for their lives (Mann 2006, 351-53, 726-28). Both end up with the Nazis, which brings an end to the friendship with Mann. Knowing how much the author relied on his personal experiences for his work, the names of his two onetime friends come as little surprise: Hans and Willi. About the latter, Mann remorsefully remarks:

I knew so many like him. Why did I not write their novel? Many novels and dramas were written about them when it was already too late. They then appeared as villains abusing Jewish philosophers in the concentration camps. But I saw them, and I liked them at a time when they were the victims and could have been saved. However, we did not care about them. (Mann 2006, 728)

Being aware of the differences between the political situation in the early 1930s and the present, there are also strong indications that there is much more awareness among today's artists for people who are disregarded by politics and the media than in the past. Taking a look at contemporary German literature, there are quite a few writers who seem to be conscious of today's (objective and subjective) Ungleichzeitigkeiten. However, these texts are definitely not as explicitly directed towards the present increase of nationalism as Mann's texts were directed towards Nazism - and that is, presumably because they were not published too late but come just at the right moment. They do 
not (yet) have to deal with Ungleichzeitigkeit being vastly exploited by nationalists ${ }^{14}$ but can stick with the task of bringing attention to one of the causes of nationalism. This is done for example by turning away from the big cities and, instead, setting novels in rural areas, small towns, or villages (e.g. Saša Stanišićs Vor dem Fest, Juli Zeh's Unterleuten, Lukas Rietzschel's Mit der Faust in die Welt schlagen) or by uncovering the ideologies in today's world of work (e.g. Thomas von Steinaecker's Das Jabr, in dem ich aufhörte, mir Sorgen zu machen, und anfing zu träumen, Terézia Mora's Der einzige Mann auf dem Kontinent). By doing so, these literary texts can be seen as a reminder that history, of course, did not come to an end - as it was suggested after the breakdown of the Soviet Union. If this indeed had been the case, the concept of Ungleichzeitigkeit would have been of no use anymore. The same is true for a view of history that only focusses on continuity. This illusive perception was, especially during the 1990s, a popular means to denounce those who brought awareness to problems within capitalism as reactionary (Vidal 1996, 14). Today, with a renewed and re-awakened nationalism, it is, in fact, history itself that unmasks the assertions of its end as mere ideologies. By pointing towards a variety of (ungleichzeitige) contradictions of the status quo, the above-mentioned literary texts do not only illustrate that history continues to progress but also that it still is the "polyrhythmic entity" $(1985 \mathrm{~g}, 618)$ Bloch talked about. While it may not be advisable to adopt every strategy Bloch proposed in order to deal with present problems (Dietschy 2018, 37-42), his general assumptions that (firstly) people living in Ungleichzeitigkeit need to be acknowledged and (secondly) they need to be addressed in a specific way remain true.

In order to briefly illustrate this with a contemporary example, this paper concludes with some remarks on Juli Zeh's Unterleuten. The title of the novel refers to a fictional village in Brandenburg. The entire novel is set in this village and many of its inhabitants are portrayed in the text - the mayor, the only entrepreneur of the village, an old communist, and townsfolk who just moved to Unterleuten. The major conflict of the novel revolves around a piece of land on which a company plans to build a wind farm; and this property in question is not owned by one but by three different persons. Concerning Ungleichzeitgkeit, one of the newcomers, Gerhard Fließ - a former professor who

${ }^{14}$ However, there are examples of how right-wing politicians take advantage of Ungleichzeitigkeit today. In the fall of 2015, when large numbers of refugees came to Germany, a political gathering took place in Magdeburg. There, Björn Höcke from the AfD expressed his hope that Germany - in the face of foreigners allegedly flooding the country - will have a thousand-year-long-future (Müller 2015). As a former teacher of history, Höcke knows that this phrase is historically contaminated, and he also knows that it probably appeals to people who are religious. Besides, there are other parallels to history concerning today's increase of nationalism - for example, superficially criticising consequences of capitalism without analysing them, followed by blaming a minority (foreigners, refugees) or copying means of propaganda from the political left (Wagner 2017, 11-13, 221-25, 228-31). 
now works for the authorities to protect the environment and just recently moved from Berlin to Unterleuten -, is most aware of it:

Although Unterleuten was only roughly one hundred kilometres away from Berlin, it could have been - from a socio-anthropological perspective - on the other side of the planet. Unnoticed by politics, the media, and science existed a semi-anarchistic, almost entirely independent way of life, [...] involuntarily subversive, far away from state influence, forgotten, neglected, and for this very reason free in a peculiar way. (Zeh 2017, 29)

Many aspects discussed earlier in this paper show themselves in this quote: There is, again, the urban-rural difference, the anticapitalist element, as well as society's ignorance towards certain ways of living. This ignorance manifests itself most clearly when an associate of the windmill company visits Unterleuten and is unable to address the villagers in an adequate manner. What is not reflected in the novel is the political exploitation of this kind of Ungleichzeitigkeit. Zeh is more interested in offering a variety of perspectives on the novel's main conflict. Thus, her book is, first and foremost, a text about tolerance because at the end the reader is able to understand every character's motives (although some of them did quite horrible things).

Having this in mind, the final word shall be given to Klaus Mann - or, to be more precise, to a character from his novel Der Vulkan. A refugee, who had to leave Germany and fled to Paris, concludes that fascism, "the new barbarism will get a cheap victory: it decapitates corpses." (Mann 1981, 260) This powerful metaphor brings attention to the question of how much damage had been done before the Nazis came to power; what mistakes had been made? And this ultimately leads to the phenomenon of Ungleichzeitigkeit. Thus, simply accepting the fact that we all share the same present, but nevertheless some of us live in totally different times might help in pushing back antidemocratic movements.

\section{References}

Bloch, Ernst. 1985a. "Brief an Klaus Mann. 4. Oktober 1933.” In Ernst Bloch. Briefe 19031975, edited by Karola Bloch et al.,Vol. 2, 622-623. Frankfurt am Main: Suhrkamp.

Bloch, Ernst. 1985b. "Brief an Klaus Mann. 15. April 1934." In Ernst Bloch. Briefe 1903-1975, edited by Karola Bloch et al., Vol. 2, 628-629. Frankfurt am Main: Suhrkamp.

Bloch, Ernst. 1985c. "Brief an Klaus Mann. 16. Mai 1935.” In Ernst Bloch. Briefe 1903-1975, edited by Karola Bloch et al., Vol. 2, 642. Frankfurt am Main: Suhrkamp. 
Bloch, Ernst. 1985d. "Brief an Klaus Mann. 27. Januar 1936." In Ernst Bloch. Briefe 19031975, edited by Karola Bloch et al., Vol. 2, 643-645. Frankfurt am Main: Suhrkamp.

Bloch, Ernst. 1985e. Erbschaft dieser Zeit (Erweiterte Ausgabe). Vol. 4 of the Ernst Bloch Gesamtausgabe. Frankfurt am Main: Suhrkamp.

Bloch, Ernst. 2007. "Geist, der sich erst bildet.” In Der unbemerkte Augenblick. Feuilletons für die Frankfurter Zeitung 1916-1934, edited by Ralf Becker, 197-209. Frankfurt am Main: Suhrkamp.

Bloch, Ernst. 1985f. Geist der Utopie. Erste Fassung (Faksimile der Ausgabe von 1918). Vol. 16 of the Ernst Bloch Gesamtausgabe. Frankfurt am Main: Suhrkamp.

Bloch, Ernst. 1985g. Philosophische Aufsätze zur objektiven Phantasie. Vol. 10 of the Ernst Bloch Gesamtausgabe. Frankfurt am Main: Suhrkamp.

Bloch, Ernst. 1985h. Politische Messungen, Pestzeit, Vormärz. Vol. 11 of the Ernst Bloch Gesamtausgabe. Frankfurt am Main: Suhrkamp.

Bloch, Ernst. 1985i. Tendenz-Latenz-Utopie. Supplementary Vol. of the Ernst Bloch Gesamtausgabe. Frankfurt am Main: Suhrkamp.

Dietschy, Beat. 1988. Gebrochene Gegenwart. Ernst Bloch, Ungleichzeitigkeit und das Geschichtsbild der Moderne. Frankfurt am Main: Vervuert.

Dietschy, Beat. 2018. "Im Mischdunkel nationaler Berauschung. Ernst Blochs Erbschaft dieser Zeit, in Zeiten des Rechtspopulismus gelesen.” Das Argument. Zeitschrift für Philosophie und Sozialwissenschaften 325: 31-44. Hamburg: Argument-Verlag.

Gekle, Hanna. 1985. "Briefe an Klaus Mann. Brief an Franz Werfel 1933-1938. Vorbemerkung.” In Ernst Bloch. Briefe 1903-1975, edited by Karola Bloch et al., Vol.2, 619. Frankfurt am Main: Suhrkamp.

Jens, Inge, and Uwe Naumann. 2011. “,Lieber Klaus` - ,Mon Oncle‘. Nachwort der Herausgeber." In Lieber und verebrter Onkel Heinrich, edited by Inge Jens and Uwe Naumann, 191-227. Reinbek bei Hamburg: Rowohlt.

Kracauer, Siegfried. 1974. Die Angestellten. Aus dem neuesten Deutschland. Frankfurt am Main: Suhrkamp.

Mann, Klaus, and Erika Mann. 1996. Escape to life. Deutsche Kultur im Exil, edited by Heribert Hoven. Reinbek bei Hamburg: Rowohlt.

Mann, Klaus. 2004. Der fromme Tanz. Das Abenteuerbuch einer Jugend. Reinbek bei Hamburg: Rowohlt.

Mann, Klaus. 1981. Der Vulkan. Roman unter Emigranten. Reinbek bei Hamburg: Rowohlt.

Mann, Klaus. 2006. Der Wendepunkt. Ein Lebensbericht (mit unbekannten Texten aus dem Nachlass), edited by Fredric Kroll. Reinbek bei Hamburg: Rowohlt.

Mann, Klaus. 2003. Flucht in den Norden. Reinbek bei Hamburg: Rowohlt.

Mann, Klaus. 1992. “Heute und Morgen. Zur Situation des jungen geistigen Europas.” In Die neuen Eltern. Aufsätze, Reden, Kritiken, 1924-1933, edited by Uwe Naumann and Michael Töteberg, 131-152. Reinbek bei Hamburg: Rowohlt.

Mann, Klaus. 1986. Mephisto. Roman einer Karriere. Berlin and Weimar: Aufbau-Verlag. 
Mann, Klaus. 1993a. "Neue Bücher.” In Zabnärzte und Künstler. Aufsätze, Reden, Kritiken, 1933-1936, edited by Uwe Naumann and Michael Töteberg, 242-253. Reinbek bei Hamburg: Rowohlt.

Mann, Klaus. 1984. Treffpunkt im Unendlichen. Reinbek bei Hamburg: Rowohlt.

Mann, Klaus. 1993b. "Woran glaubt die europäische Jugend?” In Zabnärzte und Künstler. Aufsätze, Reden, Kritiken, 1933-1936, edited by Uwe Naumann and Michael Töteberg, 348369. Reinbek bei Hamburg: Rowohlt.

Marx, Karl. 1976. The German Ideology. Vol. 5 of the Marx/Engels Collected Works. Moscow, London, New York City: Progress Publishers, Lawrence and Wishart, International Publishers.

Müller, Hanno. 2015. "Historiker: 'Höcke weiß genau, aus welchem Kontext seine Äußerungen kommen.” In Thüringer Allgemeine. Accessed 26 February 2019. https://www.thueringerallgemeine.de/web/zgt/politik/detail/-/specific/Historiker-Hoecke-weiss-genau-aus-welchemKontext-seine-Aeusserungen-kommen-1720185493.

Vidal, Francesca. 1996. "Ungleichzeitigkeit - ein Begriff der Ideologiekritik. Zur Verwendung der Kategorie ,Ungleichzeitigkeit' in den Arbeiten von Wolfram Burisch.” In Die Gegenwart des Ungleichzeitigen. In Erinnerung an Wolfram Burisch, edited by Francesca Vidal, 9-21. Mössingen-Talheim: Talheimer Verlag.

Wagner, Thomas. 2017. Die Angstmacher. 1968 und die Neuen Rechten. Berlin: AufbauVerlag.

Zeh, Juli. 2017. Unterleuten. München: btb. 